9403239

\title{
Hydrothermal Processing of Inorganic Components of Hanford Tank Sludge
}

\author{
Tank Waste Remediation Systems \\ September, 1994
}
R. Oldenborg,
S. J. Buelow
R. B. Dyer
G. Anderson
P. C. Dell'Orco
K. Funk
E. Wilmanns
K. Knutsen

\section{DISCLAIMER}

This report was prepared as an account of work sponsored by an agency of the United States Government. Neither the United States Government nor any agency thereof, nor any of their employees, makes any warranty, express or implied, or assumes any legal liability or responsibility for the accuracy, completeness, or usefulness of any information, apparatus, product, or process disclosed, or represents that its use would not infringe privately owned rights. Reference herein to any specific commercial product, process, or service by trade name, trademark, manufacturer, or otherwise does not necessarily constitute or imply its endorsement, recommendation, or favoring by the United States Government or any agency thereof. The views and opinions of authors expressed herein do not necessarily state or reflect those of the United States Government or any agency thereof.

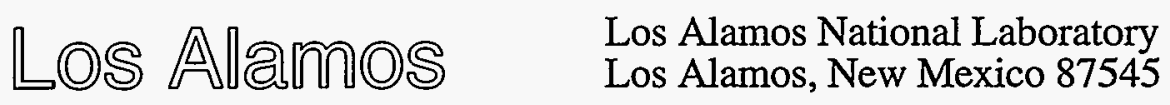




\section{DISCLAIMER}

Portions of this document may be illegible in electronic image products. Images are produced from the best available original document. 


\section{Hydrothermal Processing of Inorganic Components of Hanford Tank Sludge}

\section{Background.}

The new Triparty Agreement (TPA) establishes caustic leaching/washing methods as the baseline for Hanford sludge treatment. The purpose of this treatment is to minimize the volume of high level sludge which must be vitrified and hence reduce the volume of high level waste glass produced to a level consistent with the proposed space available in the Nevada high level repository. The caustic leaching/washing methods are designed to minimize high level waste sludge volume and thereby reduce the volume of glass which must be produced in the vitrification treatment process by removing nonradioactive constituents such as sodium, aluminum, chromium and phosphate which either are present in high abundance or can only be tolerated at low levels in the glass. However, the TPA recognized the possibility for failure of this approach and established decision points to allow for the development of more advanced processing techniques.

Thus far, experiments on caustic leaching of Hanford tank sludge from five different tanks have had highly variable results. The removal efficiency, for example, varied over a wide range for aluminum (16-85 percent), chromium (48-88 percent) and phosphorus (13-98 percent). This is undoubtedly due in part to the widely varying composition and speciation of these elements in the various tanks and even within the sludge of a single tank. In addition, many species likely to be highly intractable to simple caustic wash have been identified in Hanford tank sludge, including aluminosilicates and aluminum oxyhydroxides. Many of the alkali cations (particularly sodium) may be tied up as counterions in these intractable matrices. It seems clear that alternatives to caustic sludge leaching/washing should be investigated.

Hydrothermal Processing (HTP) is an attractive approach for the treatment of Hanford tank sludge. Hydrothermal Processing refers to a waste treatment technique in which an aqueous waste stream is fed through a chemical reactor at elevated temperatures and pressures to effect desired chemical transformations and separations. Transformations such as organic and nitrate destruction and sludge reformulation have been demonstrated at pilot scale using simulants of Hanford tank wastes. At sufficiently high temperatures and pressures $\left(>450^{\circ} \mathrm{C}, 1 \mathrm{kbar}\right)$ organics and nitrates are destroyed in seconds, producing primarily simple products such as $\mathrm{CO}_{3}{ }^{2-}, \mathrm{H}_{2} \mathrm{O}$, $\mathrm{N}_{2}, \mathrm{~N}_{2} \mathrm{O}$ and $\mathrm{OH}^{-}$, and sludges are reduced in volume and reformulated as rapid settling oxides amenable to downstream separation, or in some cases reformulated as soluble products [1-4]. Under these conditions, the waste is a fluid with densities high enough that reasonable process throughput can be achieved, but its transport properties are like those of a gas, allowing rapid chemical reaction. Oxidation and reformulation reactions take place at lower temperatures than incineration, limiting the production of $\mathrm{NO}_{\mathrm{X}}$ and char. The reactions are carried out entirely in an enclosed pressure vessel so that the heat of reaction is absorbed by the solvent and the temperature can be maintained at any desired level, typically in the range $300-550^{\circ} \mathrm{C}$. A general schematic of a Hydrothermal Processing Unit (HPU) that could have application to the Hanford Tank Wastes (HTW) is shown in Figure 1. The waste in water is pressurized and heated. Complete organic destruction is achieved without the addition of any reagents [1-3]. If further nitrate/nitrite destruction is required in addition to organic destruction, a reducing agent is added [2-4]. The waste solution is maintained at the desired reaction temperature for a time sufficient 
to achieve complete destruction of the organics and nitrates and reformulation of sludges. The mixture is then cooled, depressurized, and the gaseous, liquid and solid components separated.

Hydrothermal Processing has been under commercial development for more than three decades. In addition, the reliability of all of the components of an HPU has been demonstrated by service in the electric power industry in the last two decades. Hydrothermal waste treatment units are commercially available. The hydrothermal process when effected below the critical temperature and pressure of water is commonly called Wet Air Oxidation (WAO); above the critical temperature and pressure it is termed Supercritical Water Oxidation (SCWO). Commercial units are primarily designed to treat dilute organic wastes $(<20$ wt. \%) in water. An oxidizer (air, oxygen, hydrogen peroxide) is added to react with the organic waste. The HTW contain sufficient amounts of nitrate and nitrite so that additional oxidizer will not be needed. Except for a few applications of WAO, the waste streams treated by commercial units have a low salt content ( $<3$ wt. \%). A great deal of knowledge and experience for operating HPUs exists in the private sector. Currently, however, none of the available commercial units could be used to treat the HTW without significant modification or dilution of wastes.

The high salt content of the Hanford Tank Wastes increases the critical temperature of the mixture. Even after 3:1 dilution with water, the waste (using 101-SY as an example) can exist as both liquid and vapor phases in an HPU at temperatures as high as $550^{\circ} \mathrm{C}$. To successfully treat the unique and varied compositions of the Hanford wastes, LANL and PNL have undertaken a program, sponsored by the Tank Waste Remediation System (TWRS) to further develop hydrothermal processing technology and to tailor it to meet the specific requirements posed by TWRS. Over the past several years, the research and development infrastructure (facilities, equipment, and expertise) necessary to successfully implement the hydrothermal processing of Hanford tank wastes have been established. Laboratory test equipment and expertise for measuring physical properties, corrosion, chemical kinetics, and reaction products for Hanford tank wastes have been developed. In addition, laboratory scale batch reactors for testing "hot" simulants or small quantities of actual waste are operational in "hot" test facilities. By the end of FY94, LANL will have operational three pilot scale hydrothermal processing reactors for testing cold simulants. Two units will operate at flow rates greater than $300 \mathrm{gpd}(1000 \mathrm{ml} / \mathrm{min})$, temperatures to $575^{\circ} \mathrm{C}$, and pressures to $1.4 \mathrm{kbar}(20,000 \mathrm{psi})$. One of these units is specifically designed to treat sludges. The third unit currently operates at $2 \mathrm{gph}$.

Much of the work at LANL to date has focused on organic/ferrocyanide and nitrate/nitrite destruction. More recent work, however, has been aimed at hydrothermal dissolution and reformulation of key sludge components, including chromium, aluminum and sodium. We have successfully used caustic oxidative hydrothermal processing to solubilize both chromium and aluminum. We have also addressed the engineering issues associated with the very high solids contents of a sludge waste stream, including slurry pumping, reactor plugging, pressure letdown and solids separation.

\section{Hydrothermal Dissolution of Chromium.}

Much of our work on sludge dissolution to date has focused on the hydrothermal dissolution of Hanford tank waste simulants, particularly the intractable metal oxides and oxyhydroxides of chromium and aluminum. We have investigated both simple mixtures containing either chromium or aluminum species and more complex generic surrogates of Hanford 101-SY. 


\section{2.a. Hydrothermal Dissolution of Chromium Oxide.}

Chromium forms several oxides, as summarized in Table 1. The only oxides likely to have any appreciable concentration in Hanford sludge are the hydrous $\mathrm{Cr}_{2} \mathrm{O}_{3}$ and $\alpha-\mathrm{Cr}_{2} \mathrm{O}_{3}$. The other oxides are either unstable or very soluble in water and therefore not likely present in the sludge. Hydrous chromium oxide is readily dissolved in both acidic and basic media, although the solubility is typically low ( $\mathrm{S} \sim 10^{-4} \mathrm{~mol} / \mathrm{dm}^{3}$ ). In contrast, $\alpha-\mathrm{Cr}_{2} \mathrm{O}_{3}$ is insoluble in either strong acid or base at room temperature. At higher temperatures $\alpha-\mathrm{Cr}_{2} \mathrm{O}_{3}$ is slightly soluble in strong base. Between 210 and $260^{\circ} \mathrm{C}$, in $5 \mathrm{M} \mathrm{NaOH}$, the solubility reaches approximately $10^{-4}$ $\mathrm{M} \mathrm{Cr}(\mathrm{III})$. The kinetics of dissolution are very slow however, requiring over $3 \mathrm{~h}$ to reach equilibrium.

Chromium species having higher oxidation states than II, particularly VI, tend to have much higher solubilities in water. Consequently dissolution of $\alpha-\mathrm{Cr}_{2} \mathrm{O}_{3}$ is often accomplished by oxidation, for example in well known large-scale industrial cleaning processes of stainless steel surfaces. Oxidative dissolution is particularly favorable in alkaline conditions. An alkaline mixture of potassium permanganate (a good oxidant) is used in the classical industrial procedure for the dissolution of $\alpha-\mathrm{Cr}_{2} \mathrm{O}_{3}$ [6]. Oxygen and hydrogen peroxide are also effective as oxidants $[7,8]$. The reactions at room temperature are still very slow, however. We expected the rates of dissolution to be greater for hydrothermal conditions and so we initiated a study of the hydrothermal oxidative dissolution of $\alpha-\mathrm{Cr}_{2} \mathrm{O}_{3}$.

Table 1. Properties of the Oxides of Chromium [5]

\begin{tabular}{|c|c|c|c|c|}
\hline $\begin{array}{c}\text { Oxidation } \\
\text { State }\end{array}$ & Oxide & Structure & Stability in water & $\begin{array}{l}\text { Acid/Base } \\
\text { Properties }\end{array}$ \\
\hline \multirow[t]{5}{*}{ III } & $\mathrm{Cr}(\mathrm{OH})_{3}\left(\mathrm{H}_{2} \mathrm{O}\right)_{3}$ & modified bayerite & $\begin{array}{l}\text { dissolves or } \\
\text { decomposes }\end{array}$ & amphoteric \\
\hline & $\mathrm{Cr}(\mathrm{OH})_{3} \cdot 3 \mathrm{H}_{2} \mathrm{O}$ & contains dimers & $\begin{array}{l}\text { dissolves or } \\
\text { decomposes }\end{array}$ & amphoteric \\
\hline & $\alpha-\mathrm{Cr}_{2} \mathrm{O}_{3}$ & corundum & stable; insoluble & amphoteric \\
\hline & hydrous $\mathrm{Cr}_{2} \mathrm{O}_{3}$ & amorphous & reasonably stable & amphoteric \\
\hline & $\mathrm{CrOOH}$ & polymorphic & metastable & amphoteric \\
\hline IV & $\mathrm{CrO}_{2}$ & rutile & $\begin{array}{l}\text { releases } \mathrm{O}_{2} \text { unless } \\
\text { passivated }\end{array}$ & - \\
\hline \multirow[t]{2}{*}{ VI } & $\mathrm{CrO}_{3}$ & $\begin{array}{c}\text { chains of } \mathrm{CrO}_{4} \\
\text { tetrahedra }\end{array}$ & $\begin{array}{l}\text { decomposes } \\
\text { (strong oxidant) }\end{array}$ & $\begin{array}{l}\text { strongly acidic; } \\
\text { forms } \mathrm{HCrO}_{4}^{-}\end{array}$ \\
\hline & $\mathrm{CrO}_{5}$ & $\begin{array}{l}\text { contains two } \\
\text { peroxide groups }\end{array}$ & limited stability & strongly acidic \\
\hline
\end{tabular}

Chromium in sludges most likely exists as the extremely insoluble oxide, $\alpha-\mathrm{Cr}_{2} \mathrm{O}_{3}$, having chromium in the plus III oxidation state. We have attempted to solubilize $\alpha-\mathrm{Cr}_{2} \mathrm{O}_{3}$ by oxidation under hydrothermal conditions, according to the following reaction: 


$$
\alpha-\mathrm{Cr}_{2} \mathrm{O}_{3}+4 \mathrm{NaOH}+3 \mathrm{H}_{2} \mathrm{O}_{2} \Delta 2 \mathrm{Na}_{2} \mathrm{CrO}_{4}+5 \mathrm{H}_{2} \mathrm{O}
$$

We selected hydrogen peroxide as the oxidant for these initial studies because of the ease of handling of this oxidant and because it is known to oxidize $\mathrm{Cr}(\mathrm{II})$ to $\mathrm{Cr}$ (VI). The product of this reaction is sodium chromate, a yellow salt that is highly soluble in water. The chromium is oxidized from $\mathrm{Cr}(\mathrm{III})$ to $\mathrm{Cr}(\mathrm{VI})$, while hydrogen peroxide is reduced to water. The reaction consumes base $(\mathrm{NaOH})$, which in many cases is already present in high concentrations in the tank waste. The reaction also consumes oxidant; either gaseous oxygen or an aqueous solution of hydrogen peroxide is used. The $\Delta \mathrm{H}$ of this reaction calculated from heats of formation is -120 $\mathrm{kcal} / \mathrm{mol}$.

Another reaction is possible under hydrothermal conditions, namely:

$$
\alpha-\mathrm{Cr}_{2} \mathrm{O}_{3}+2 \mathrm{NaOH}+3 \mathrm{H}_{2} \mathrm{O}_{2} \Delta \mathrm{Na}_{2} \mathrm{Cr}_{2} \mathrm{O}_{7}+4 \mathrm{H}_{2} \mathrm{O}
$$

The product of this reaction is sodium dichromate, a red salt that is also highly soluble in water. In this case the chromium is also oxidized from $\mathrm{Cr}(\mathrm{III})$ to $\mathrm{Cr}(\mathrm{VI})$, while hydrogen peroxide is reduced to water. The formation of chromate or dichromate depends on hydroxide ion concentration.

Experiments have been conducted based on the stoichiometry of reaction 2.2 , in an attempt to convert chromium oxide to dichromate. The experiments were run using a flow reactor constructed with a Hasteloy $\mathrm{C} 276$ tube (a high nickel alloy). The $\alpha-\mathrm{Cr}_{2} \mathrm{O}_{3}$ was prepared as a slurry by mixing $1 \mathrm{~g}$ of the finely divided powder in $500 \mathrm{~mL}$ of water. The slurry was introduced into the reactor by pumping through a high pressure liquid chromatography (hplc) pump. The slurry was pumped into the reactor in this way for several hours without clogging the pump or feed lines and without degrading the pump seals. The base (sodium hydroxide) and oxidant (hydrogen peroxide) were introduced with a separate hplc pump and the two feed streams were mixed cold and then injected into the reactor. A filter was placed after the heat exchanger and before the pressure let-down valve to trap any unreacted solid $\alpha-\mathrm{Cr}_{2} \mathrm{O}_{3}$.

The first experiments were carried out at $400^{\circ} \mathrm{C}$ and $5500 \mathrm{psi}$. The total flow rate was 8 $\mathrm{ml} / \mathrm{min}$, yielding a nominal residence time in the reactor of 15 seconds. The actual residence time depends in part on the transport of the $\alpha-\mathrm{Cr}_{2} \mathrm{O}_{3}$ through the reactor, which may be slower than the transport of the water and dissolved reactants/products. The reactor effluent was analyzed for chromium using an atomic absorption spectrometer. The strong yellow color of the effluent solutions suggests that the $\mathrm{Cr}$ has been converted to chromate (dichromate would be a distinctive red color). The actual form of $\mathrm{Cr}$ was determined by its $\mathrm{UV}$-Vis absorption spectrum to be chromate. The overall conversion efficiency (the fraction of insoluble $\alpha-\mathrm{Cr}_{2} \mathrm{O}_{3}$ converted to the soluble chromate ion) was determined by measuring the weight of $\mathrm{Cr}$ introduced into the reactor and analytically determining the weight of soluble $\mathrm{Cr}$ produced in the reactor effluent using atomic absorption. The conversion efficiency determined in this manner is $24 \%$. This number represents a lower limit for the conversion efficiency, because some $\alpha-\mathrm{Cr}_{2} \mathrm{O}_{3}$ was trapped in the pump and feed lines and never actually introduced into the reactor. The amount trapped was not determined, but could have been as much as $10 \%$ of the $\mathrm{Cr}$ in the slurry. $\mathrm{Cr}$ appears to be very soluble under the reactor conditions employed since very little Cr was recovered when the reactor was flushed after the reaction. The unreacted $\mathrm{Cr}$ was recovered as the solid $\alpha-\mathrm{Cr}_{2} \mathrm{O}_{3}$, trapped in the filter after the reactor. 
A second set of experiments was carried out at $600{ }^{\circ} \mathrm{C}$ and 5500 psi. The total flow rate was $4 \mathrm{ml} / \mathrm{min}$, yielding a residence time of about 11 seconds (nearly the same as the first run due to the reduced density). The soluble $\mathrm{Cr}$ product was also a bright yellow color due to the formation of chromate. The conversion efficiency increased to $66 \%$ in this case. An important difference in these experiments was that most of the $\mathrm{Cr}$ did not appear in the reactor effluent while running at $600^{\circ} \mathrm{C}$ and $5500 \mathrm{psi}$, but appeared later when the reactor was cooled and flushed. It is possible the solubility of $\mathrm{Na}_{2} \mathrm{CrO}_{4}$ is greatly reduced at this density. One solution to this problem is to increase the density by increasing the pressure. Future experiments will examine the solubility of $\mathrm{Na}_{2} \mathrm{CrO}_{4}$ as a function of fluid density.

There are several possible approaches to increasing the efficiency of conversion of $\alpha-$ $\mathrm{Cr}_{2} \mathrm{O}_{3}$ to $\mathrm{Na}_{2} \mathrm{CrO}_{4}$. The most obvious approach is to increase the concentration of base employed. The stoichiometry chosen for these reactions was that of equation 2 , for the reaction that produces dichromate. It appears that hydrothermal conditions favor the production of chromate, however, so that twice the amount of base is needed for complete reaction. In addition, the residence time can be increased and an excess of oxidant can be employed. Finally, the pressure can be increased in order to increase the density and hence the solubility of the $\mathrm{Na}_{2} \mathrm{CrO}_{4}$ product. The effects of all of these factors will be explored in future experiments.

We have also investigated these reactions in a small volume $(\sim 4.0 \mathrm{ml})$ batch reactor. We find that under hydrothermal conditions, at $480^{\circ} \mathrm{C}$ and with an excess of oxidant, the $\alpha-\mathrm{Cr}_{2} \mathrm{O}_{3}$ oxide is completely converted $(>99 \%)$ to a soluble chromium species in 30 minutes. The kinetics of chromium dissolution have been determined for a limited set of conditions $\left(\sim 480^{\circ} \mathrm{C}\right.$ and $5000 \mathrm{psi}$ ). The kinetics of this process are illustrated in Figure 2, together with an exponential fit to the data. The reaction appears to be first order in chromium with a half life of approximately 10 minutes. One difficulty with these results is the relatively long heat-up and cool-down times required by this batch reactor distort the actual reaction time since significant reaction may occur in both of these periods. We have recently built a more efficient heating system that allows rapid (1-2 minutes) heating and quenching. This approach will give us much better control over our residence times. In addition, since most of our flow reactors (including our $300 \mathrm{gal} / \mathrm{hour}$ reactor) have residence times shorter than 5 minutes, it is important to speed up this reaction to achieve significant chromium dissolution for high throughput flow conditions. It is very likely that increased temperature, pressure (density) and oxidant concentration will succeed in improving the reaction rate. These issues will be explored in future studies. The soluble chromium species has a UV-vis absorption spectrum that is consistent with chromate. A standard colorimetric analysis for chromate is being developed and will be used to quantitate chromate produced in this reaction.

We have been conducting these reactions in a batch reactor made of stainless steel. A major disadvantage of this reactor is that the stainless steel is approximately $18 \%$ chromium. Corrosion of the reactor could therefore result in contamination of the reactor effluent with chromium leached from the reactor walls. We have addressed this problem in two ways. First, we have conducted blank control reactions having only the base and oxidant and no added chromium to assess the degree of corrosion production of soluble chromium. We have found that even in the worst case, the production of soluble chromium by corrosion is less than $10 \%$ of the total production of soluble chromium in an actual chromium run. Apparently this batch reactor has been passivated to chromium leaching by previous runs with oxidant and base. Based on past experience with other hydrothermal reactions, however, we feel it is possible for the leaching rate of $\mathrm{Cr}$ from the reactor to change, if for example, the reaction conditions are 
changed. It is therefore risky at best to assume that the leach rate does not vary and control runs are therefore always necessary to validate the results from this reactor. Because of the large time investment required for these control runs, we have investigated other approaches which avoid the $\mathrm{Cr}$ leaching problem altogether. We have designed a new reactor which is gold lined to prevent contact of the reactants with the stainless steel. This reactor has been built and is in the process of being gold-coated. Another reactor design uses a nickel alloy with no chromium content. However, this material is not as strong as stainless steel and will limit the pressure and temperature range of our reactions to $6000 \mathrm{psi}$ and $450{ }^{\circ} \mathrm{C}$. These new reactors will allow us to greatly increase our productivity and quality assurance.

\section{2.b. Hydrothermal oxidation of chromium with nitrate.}

We have started to explore the possibility of using other oxidants to effect the oxidation of $\alpha-\mathrm{Cr}_{2} \mathrm{O}_{3}$ to chromate. Since both nitrate and nitrite are present in both the sludge and effluent of Hanford tank wastes, we decided to explore the feasibility of using these mild oxidants for hydrothermal oxidation of $\alpha-\mathrm{Cr}_{2} \mathrm{O}_{3}$. We have conducted the following reaction under hydrothermal conditons in the Inconel 625 batch reactor:

$$
\alpha-\mathrm{Cr}_{2} \mathrm{O}_{3}+2 \mathrm{NaOH}+\mathrm{NaNO}_{3}+\mathrm{NaNO}_{2} \Delta 2 \mathrm{Na}_{2} \mathrm{CrO}_{4}+\mathrm{H}_{2} \mathrm{O}+\text { gaseous products }
$$

This reaction is not as favorable thermodynamically as the oxidation using hydrogen peroxide. Calculation of the enthalpy of reaction using heats of formation suggests that it is nearly thermoneutral. The reaction was carried out in a small volume batch reactor at $500{ }^{\circ} \mathrm{C}$ and 10,000 psi. With reaction times greater than 15 minutes, the oxidation of $\alpha-\mathrm{Cr}_{2} \mathrm{O}_{3}$ appeared to be nearly complete (as determined by disappearence of the insoluble $\alpha-\mathrm{Cr}_{2} \mathrm{O}_{3}$ phase, a green solid clearly visible in the bottom of the reactor), with the production of a strongly yellow colored solution characteristic of chromate. Gaseous products were detected but not quantified. A qualitative FTIR showed $\mathrm{N}_{2} \mathrm{O}$ present as a product. Other likely products are $\mathrm{N}_{2}$ and $\mathrm{O}_{2}$ which could not be detected in the FTIR. Quantitative product analysis and determination of the kinetics of this reaction are underway.

\section{2.c. Hydrothermal oxidation of chromium in 101-SY simulant.}

We have conducted a number of experiments on a 3:1 diluted simulant for tank 101-SY. These experiments demonstrate the feasibility of hydrothermal processing of waste streams with very high solids loading. The composition of the 101-SY simulant, based on reference 9 , is given in Table 2. Figure 3 shows the solubilized fraction of chromium in the effluent as a function of temperature for all experiments conducted using the 3:1 diluted simulant 101-SY. As indicated on the graph, chromium appears as a relatively insoluble species in the effluent at temperatures near $380^{\circ} \mathrm{C}(1 / \mathrm{T} \sim 0.0015)$. With increasing temperature, however, chromium is recovered primarily as a soluble species. Above $450^{\circ} \mathrm{C}(1 / \mathrm{T} \sim 0.0014)$, greater than $60 \%$ of the chromium is recovered as a soluble species. Above $500^{\circ} \mathrm{C}$, greater than $100 \%$ is recovered as soluble; this results from the fact that insoluble chromium is left in the reactor at the lower temperatures, and reconstituted to a soluble form when the temperature of the bench-scale reactor is increased. This reconstitution is also evident in the coloration of the sludge effluent and effluent particulates, which change from a dark green to a bright yellow color as the temperature 
increases from $380^{\circ} \mathrm{C}$ to $500^{\circ} \mathrm{C}$ at 1.0 to $1.3 \mathrm{kbar}$. Presumably, particulate $\mathrm{Cr}(\mathrm{III})$, as $\alpha-\mathrm{Cr}_{2} \mathrm{O}_{3}$ or $\mathrm{Cr}(\mathrm{OH})_{3}$ produced the dark green color, while soluble $\mathrm{Cr}(\mathrm{VI})$, as $\mathrm{CrO}_{4}=$, produced the yellow color. Similar reconstitution behavior was observed with calcium, strontium, and zinc.

\begin{tabular}{|c|c|c|c|}
\hline Component & $\begin{array}{l}\text { Molality } \\
(\mathrm{mol} / \mathrm{kg}) \\
\end{array}$ & $\begin{array}{c}\text { Molarity } \\
(\mathrm{mol} / \mathrm{L})\end{array}$ & wt\% \\
\hline $\mathrm{Na}^{+}$ & 3.910 & 3.526 & 7.05 \\
\hline $\mathrm{NO}_{2}^{-}$ & 1.012 & 0.913 & 3.65 \\
\hline $\mathrm{NO}_{3}^{-}$ & 0.837 & 0.755 & 4.07 \\
\hline $\mathrm{OH}^{-}$ & 0.763 & 0.689 & 1.02 \\
\hline $\mathrm{AlO}_{2}^{-}$ & 0.530 & 0.478 & 2.45 \\
\hline $\mathrm{CO}_{3}{ }^{2-}$ & 0.233 & 0.210 & 1.10 \\
\hline $\mathrm{Cl}^{-}$ & 0.099 & 0.089 & 0.27 \\
\hline EDTA $^{4-}$ & 0.056 & 0.051 & 1.28 \\
\hline $\mathrm{K}^{+}$ & 0.037 & 0.033 & 0.11 \\
\hline $\mathrm{Cr}^{3+}$ & 0.035 & 0.032 & 0.14 \\
\hline $\mathrm{PO}_{4}^{3-}$ & 0.030 & 0.027 & 0.22 \\
\hline $\mathrm{SO}_{4}{ }^{2-}$ & 0.018 & 0.017 & 0.14 \\
\hline $\mathrm{F}^{-}$ & 0.007 & 0.006 & 0.010 \\
\hline $\mathrm{Ca}^{2+}$ & 0.003 & 0.002 & 0.008 \\
\hline $\mathrm{Fe}^{3+}$ & 0.002 & 0.002 & 0.010 \\
\hline $\mathrm{Ni}^{2+}$ & 0.001 & 0.001 & 0.005 \\
\hline $\mathrm{Zn}^{2+}$ & $1.38 \times 10^{-4}$ & $1.25 \times 10^{-4}$ & $7.09 \times 10^{-4}$ \\
\hline $\mathrm{Cs}^{+}$ & $4.69 \times 10^{-5}$ & $4.23 \times 10^{-5}$ & $4.89 \times 10^{-4}$ \\
\hline $\mathrm{Sr}^{2+}$ & $3.01 \times 10^{-6}$ & $2.71 \times 10^{-6}$ & $2.08 \times 10^{-5}$ \\
\hline $\mathrm{H}_{2} \mathrm{O}$ & 55.5 & 63.889 & 78.43 \\
\hline
\end{tabular}

\section{Hydrothermal Dissolution of Aluminum-bearing sludges.}

Sludges in which aluminum has been precipitated from a basic aqueous solution may contain several forms of aluminum hydroxide and oxyhydroxides. The forms may depend on the presence of other salts in the original solution, and may have been modified by reactions subsequent to precipitation. Some of the possible forms in which aluminum may exist in sludges are listed below:

Bayerite - $\mathrm{Al}(\mathrm{OH})_{3}$ 


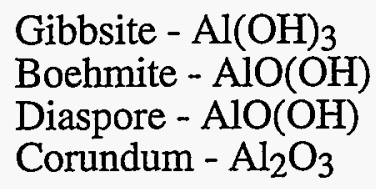

In addition, aluminum probably exists in mixed salts such as the aluminosilicates. All of the above species except aluminosilicates and corundum are amenable to redissolution in basic media, since they have relatively large solubilities. The solubilities increase with temperature; Figure 4, for example, shows the solubility constant as a function of temperature for gibbsite, as reported by Apps and Neil [10]. The data that they report extend from room temperature to $350^{\circ} \mathrm{C}$. The dissolution of aluminum hydroxides is most likely rate limited, and should therefore be faster at higher temperatures; however, solubility data is not generally available for hydrothermal conditions. Indeed, discrepancies are often reported in the literature on the solubilities of aluminum-containing compounds, and are ascribed to the failure to reach equilibrium. By virtue of the high temperatures and densities employed, hydrothermal processing offers an attractive means to overcome the rate limitations inherent in the redissolution of aluminum-bearing solids. Hydrothermal processing is commonly employed by the aluminum industry for processing aluminum ores. There is also a wealth of information in the geochemical literature on the hydrothermal dissolution of aluminum oxide (corundum) and aluminosilicates.

\section{3.a. Solubility of Aluminum Compounds in Caustic Hydrothermal Media.}

Hydrothermal processing of aluminum is generally carried out in solutions of high hydroxide concentration. The presence of excess hydroxide in solution causes the formation of "aluminate" ions, sometimes written as $\mathrm{AlO}_{2}{ }^{-}$, but more properly written as $\mathrm{Al}(\mathrm{OH})_{4}\left(\mathrm{H}_{2} \mathrm{O}\right)_{2}{ }^{-}$. We will abbreviate aluminate ions as $\mathrm{Al}(\mathrm{OH})_{4}^{-}$.

$$
\mathrm{Al}+\mathrm{NaOH}+3 \mathrm{H}_{2} \mathrm{O} \Delta \mathrm{NaAl}(\mathrm{OH})_{4}+1.5 \mathrm{H}_{2}
$$

Sodium aluminate is highly soluble in water at room temperature, particularly in solutions of high $\mathrm{pH}$, since high $\mathrm{pH}$ suppresses the formation of the insoluble compounds gibbsite, $\mathrm{Al}(\mathrm{OH})_{3}$, and boehmite, $\mathrm{AlOOH}$.

$$
\begin{aligned}
& \mathrm{Al}(\mathrm{OH})_{4}{ }^{-}(\mathrm{aq}) \Delta \mathrm{Al}(\mathrm{OH})_{3}(\mathrm{~s})+\mathrm{OH}^{-}(\mathrm{aq})(3.2) \\
& \mathrm{Al}(\mathrm{OH})_{4}{ }^{-}(\mathrm{aq}) \Delta \mathrm{AlOOH}(\mathrm{s})+\mathrm{OH}^{-}(\mathrm{aq})+\mathrm{H}_{2} \mathrm{O}
\end{aligned}
$$

It is important to maintain high $\mathrm{pH}$ since Tikhonov [11] reports that, at low $\mathrm{pH}$, the aluminum hydroxide gradually converts to boehmite at room temperature, and boehmite converts to alumina $\left(\mathrm{Al}_{2} \mathrm{O}_{3}\right)$ above $600{ }^{\circ} \mathrm{C}$. [The above discussion is somewhat oversimplified since $\mathrm{Al}(\mathrm{OH})_{3}$ and $\mathrm{AlOOH}$ each have two isomers]. The reaction sequence

$$
\text { aluminate } \rightarrow \text { gibbsite } \rightarrow \text { boehmite } \rightarrow \text { alumina }
$$

would cause severe plugging problems in a flow reactor since the last three species are highly insoluble at low pH. A much more favorable situation exists at high $\mathrm{pH}$. Apps and Neil [10] 
measured the equilibrium constants for reactions 3.2 and 3.3 between 0 and $350{ }^{\circ} \mathrm{C}$. They found gibbsite and boehmite to be highly soluble in basic solutions, with solubility increasing with temperature along the vapor saturation curve. Extension to temperatures above the critical temperature of water is not straightforward, however. The presence of dissolved salts raises the liquid-vapor critical temperature of the solution, so that multi-phase behavior is possible at temperatures well in excess of $374{ }^{\circ} \mathrm{C}$. Also, the dielectric strength of water decreases dramatically with increasing temperature and decreasing density above $\mathrm{T}_{\mathrm{c}}$. Therefore, salt solubilities are expected to decrease with increasing temperature, regardless of whether the system is a liquid, vapor, or supercritical fluid. Data in the literature are nonexistent for the system of interest above $350^{\circ} \mathrm{C}$. New experimental data are required to ascertain whether aluminum salts will stay in solution during hydrothermal processing.

\section{3.b. Experimental Techniques for the Study of Solubility and Phase Behavior.}

Two experimental approaches have been employed to study phase behavior and solubility in hydrothermal systems. One approach uses an optical cell to observe the behavior of static solutions as they are heated under high pressure. By decreasing the applied pressure at constant temperature, phase changes (crystallization of solids, appearance of molten salts, vapor-liquid equilibria) can be observed visually or by their effect on the optical transmission of the cell. The other approach uses a packed-bed flow tube to measure salt solubilities (Figure 5). Solutions initially at room temperature are pumped at high pressure into a heated packed bed, after which they are cooled and passed through a pressure letdown valve. If the salt concentration entering the packed bed exceeds the solubility at the final temperature and pressure, salt will precipitate in the bed and the solution exiting the cell will be saturated with salt. Inductively coupled plasma spectroscopy and acidimetric titration analysis of the effluent stream gives a direct measurement of salt concentration and hence solubility. This method probably works best for salts that separate out as solids rather than molten salts, since molten salts may partially or completely flow out of the packed bed and be redissolved in the cooldown section. Since sodium aluminate has a very high melting point, it will separate out as a solid. Sodium hydroxide, on the other hand, is molten at the temperatures used in this study. In principle, the packed-bed method works for sub- or supercritical temperatures, and for any pressure, with one possible exception. If the temperature is subcritical and the pressure is in the two-phase liquid-vapor (or liquidliquid) region, there is no direct method for distinguishing what fraction of the fluid is in each phase, and so the solubility cannot be found unambiguously in either phase.

\section{3.c. Optical Cell Studies of Basic Aluminate Solution Solubilities}

A series of solutions with varying aluminate concentrations were made in 1.0 molar sodium hydroxide solutions. Aluminate solutions were studied at temperatures of $375,400,425$, 450 , and $475^{\circ} \mathrm{C}$. The experiments consisted of heating the solutions up to the desired temperature at high initial pressure, followed by lowering the pressure until a phase change was observed. In all cases except for the most dilute aluminate solution at the highest temperature, the solutions displayed normal vapor-liquid equilibria. No precipitates were observed as long as the systems were in the liquid phase. For the 0.5 molar aluminate solution at $475^{\circ} \mathrm{C}$, no vaporliquid phase transition was observed; instead, a solid phase was seen to separate out when the pressure dropped to about 7700 psia. The vapor pressure data are summarized in Table 3 . It is 
clear from these data that sodium aluminate is highly soluble in basic solutions at sufficiently high pressures, whether or not the solutions are above their critical temperatures.

Table 3. Vapor Pressures for Sodium Aluminate Solutions in 1.0 Molar Sodium Hydroxide

\begin{tabular}{ccc}
\hline $\mathbf{T}\left({ }^{\circ} \mathbf{C}\right)$ & \multicolumn{2}{c}{ Pv (psia) } \\
\hline 375 & 0.5 molar aluminate & 2.0 molar aluminate \\
400 & 2930 & 2844 \\
425 & 4011 & 3826 \\
450 & 5203 & 5254 \\
475 & 6597 & 7018 \\
\hline
\end{tabular}

\section{3.d. High Temperature, Low Density Salt Solubility Studies in the Packed-Bed Flow Apparatus.}

Several measurements were made to determine sodium aluminate solubility in supercritical sodium hydroxide solutions as a function of temperature and pressure. The feed salt solutions for these experiments were made in 0.1 molar sodium hydroxide so that supercritical behavior could be achieved at the temperatures studied $\left(400-475^{\circ} \mathrm{C}\right)$. Hydroxide concentrations were determined by acidimetric titration and aluminum and sodium concentrations were determined by inductively coupled plasma spectroscopy. With the determined concentrations of all species in effluent samples the solubility of sodium aluminate in the supercritical fluid phase was calculated. Table 4 shows the results of the packed-bed flow apparatus solubility studies and confirms that, as anticipated, the supercritical phase solubility of sodium aluminate is low $(<3 \mathrm{~g} / \mathrm{kg})$ at these relatively moderate pressures.

Table 4. Supercritical Phase Solubility of Sodium Aluminate

\begin{tabular}{cccc}
\hline Electrolyte & \multicolumn{1}{c}{$\mathbf{T}\left({ }^{\circ} \mathbf{C}\right)$} & $\mathbf{P}(\mathbf{p s i a})$ & $\mathbf{S}(\mathbf{m g} / \mathbf{k g})$ \\
\hline sodium aluminate & $399.7 \pm 2.6$ & $5045 \pm 34$ & $201 \pm 34$ \\
& $424.9 \pm 2.6$ & $5112 \pm 123$ & $182 \pm 38$ \\
& $450.1 \pm 1.8$ & $5025 \pm 48$ & $75 \pm 12$ \\
& $475.5 \pm 1.8$ & $5026 \pm 57$ & $59 \pm 6$ \\
& $450.2 \pm 0.5$ & $6800 \pm 158$ & $1530 \pm 82$ \\
& $450.3 \pm 0.2$ & $7926 \pm 312$ & $2284 \pm 68$ \\
\hline
\end{tabular}

Presently, the available solubility data for sodium aluminate covers a very small part of the range of temperature, pressure and overall composition that is possible. At the highest pressures, the data are semiquantitative; only lower bounds on solubility may be established. A 
few general conclusions are obvious, however. First, the pressure (and its effect on the density and phase) has an enormous effect on salt solubility. Typical solubilities at $450^{\circ} \mathrm{C}$ and 5000 psia are on the order of grams $/ \mathrm{kgH}_{2} \mathrm{O}$ or less, while at $450^{\circ} \mathrm{C}$ and 10,000 psia, solubilities are on the order of $100 \mathrm{grams} / \mathrm{kg} \mathrm{H}_{2} \mathrm{O}$ or more. Second, excess sodium hydroxide can have an enormous effect on solubility, presumably by the creation of a "melt" phase.

\section{Future Directions.}

While the work summarized in this report represents an important foundation for the evaluation of the potential of Hydrothermal Processing for the dissolution of Hanford tank waste, it is important to emphasize that a critical evaluation of this technology must be based on data from actual tank waste. We have recently assembled both flow and batch reactors with the capability of processing actual HTW. We also have extensive analytical capablities for the analysis of hot samples, including determination and speciation of all of the metals and ions expected to be important in the dissolution process. We expect to receive a sample from 101-SY in July, and begin processing it soon thereafter.

\section{References}

1. Foy, B.R. et al., "Kinetics of Organic Oxidation by Nitrate in Hydrothermal Systems." Los Alamos Unclassified Report, LA-UR-93-3147, September, 1993.

2. Dell'Orco, P.C., C. A. Arrington, G. R. Brewer, H.K. Eaton, B.R. Foy, D.M. Harradine, L.A. Le, D.A. Masten, R.D. McFarland, J.M. Robinson, E.G. Wilmanns, and S.J. Buelow. "Kinetics of Nitrate and Nitrite Reduction Reactions in Hydrothermal Systems," Los Alamos Unclassified Report, LA-UR-93-3146 (1993b).

3. Dell'Orco, P.C., B.R. Foy, J.M. Robinson, and S.J. Buelow, "Hydrothermal Treatment of Hanford Tank Waste Constituents," Haz. Waste./Haz. Mat. 10 (1993a): 221.

4. Robinson, J.M., B.R. Foy, P.C. Dell'Orco, G. Anderson, F. Archuleta, J. Atencio, D. Breshears, R. Brewer, H. Eaton, R. McFarland, R. McInroy, T. Reynolds, M. Sedillo, E. Wilmanns, and S.J. Buelow. "Destruction of Nitrates, Organics, and Ferrocyanides by Hydrothermal Processing," Waste Management '93 Conference Proceedings, Tucson, AZ, Feb./Mar., 1993., p. 709-716.

5. Blesa, M. A., Morando, P. J., Regazzoni, A. E., in Chemical Dissolution of Metal Oxides, CRC Press, Boca Raton, 1994, p 310.

6. Segal, M. G. and Williams, W. J., J. Chem. Soc., Faraday Trans. I, 82, 3245, 1986.

7. Farrow, C.J. and Burkin, A. R., in Leaching and Reduction in Hydrometallurgy, Burkin, A. R., Ed., The Institute of Mining and Metallurgy, London, 1975, 20.

8. Reartes, G., Morando, P. J., Blesa, M. A., Hewlett, P., and Matijevic, E., Chem. Mater, 3, $1101,1991$.

9. Hohl, T. M. "Synthetic Waste Formulations for Representing Hanford Tank Wastes," Westinghouse-Hanford Company Report. WHC-SD-WM-TI-549, May, 1993.

10. Apps, J., and Neil, J., "Solubilities of Aluminum hydroxides and Oxyhydroxides in Alkaline Solutions," in Chemical Modeling of Aqueous systems II, ACS, 1990, pp 415-428.

11. Tikhonov, V.N., Analytical Chemistry of Aluminum, John Wiley and Sons, New York, pp 6$8,1973$. 


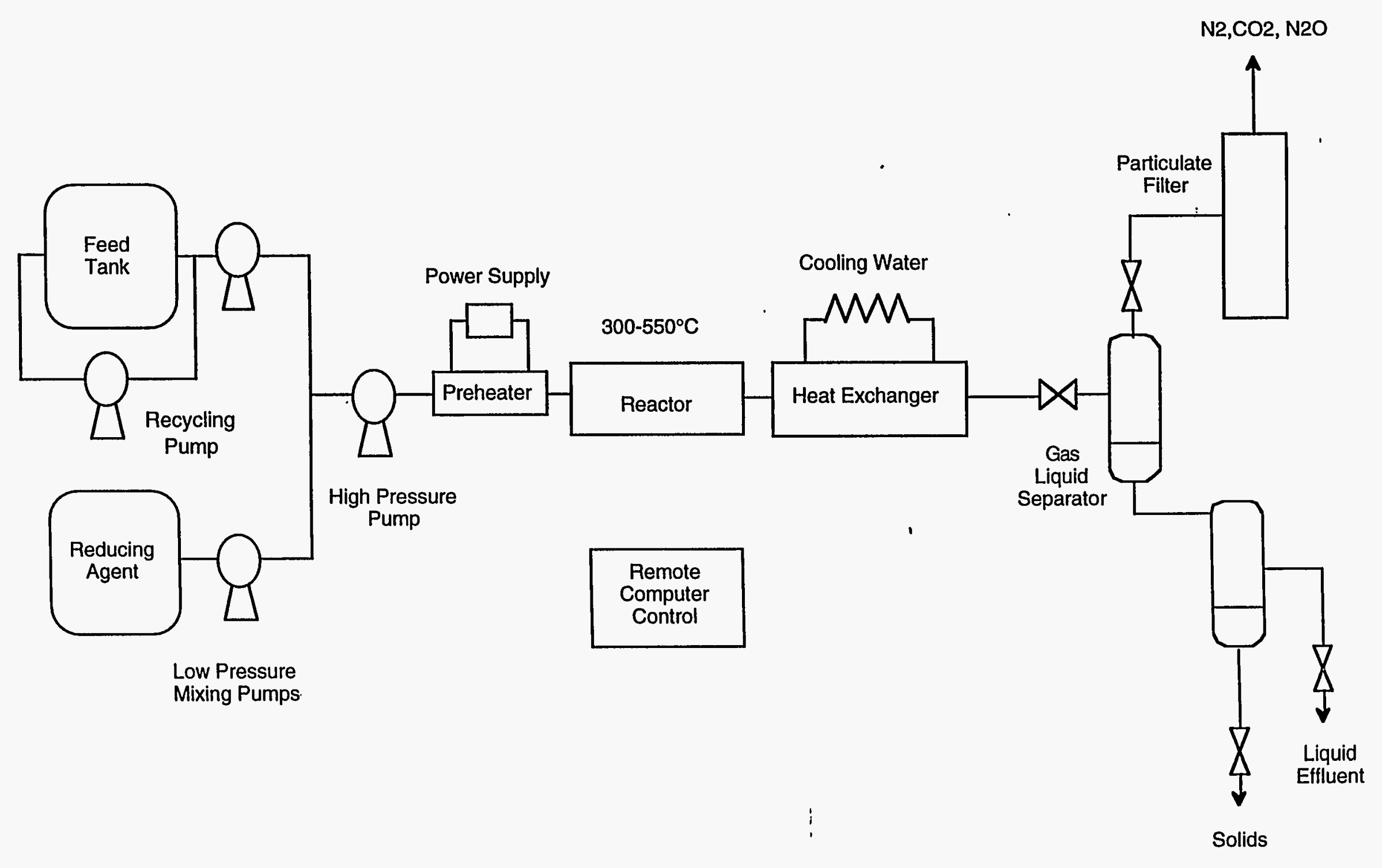

Figure 1. Schematic Diagram of Hydrothermal Processing Unit. 


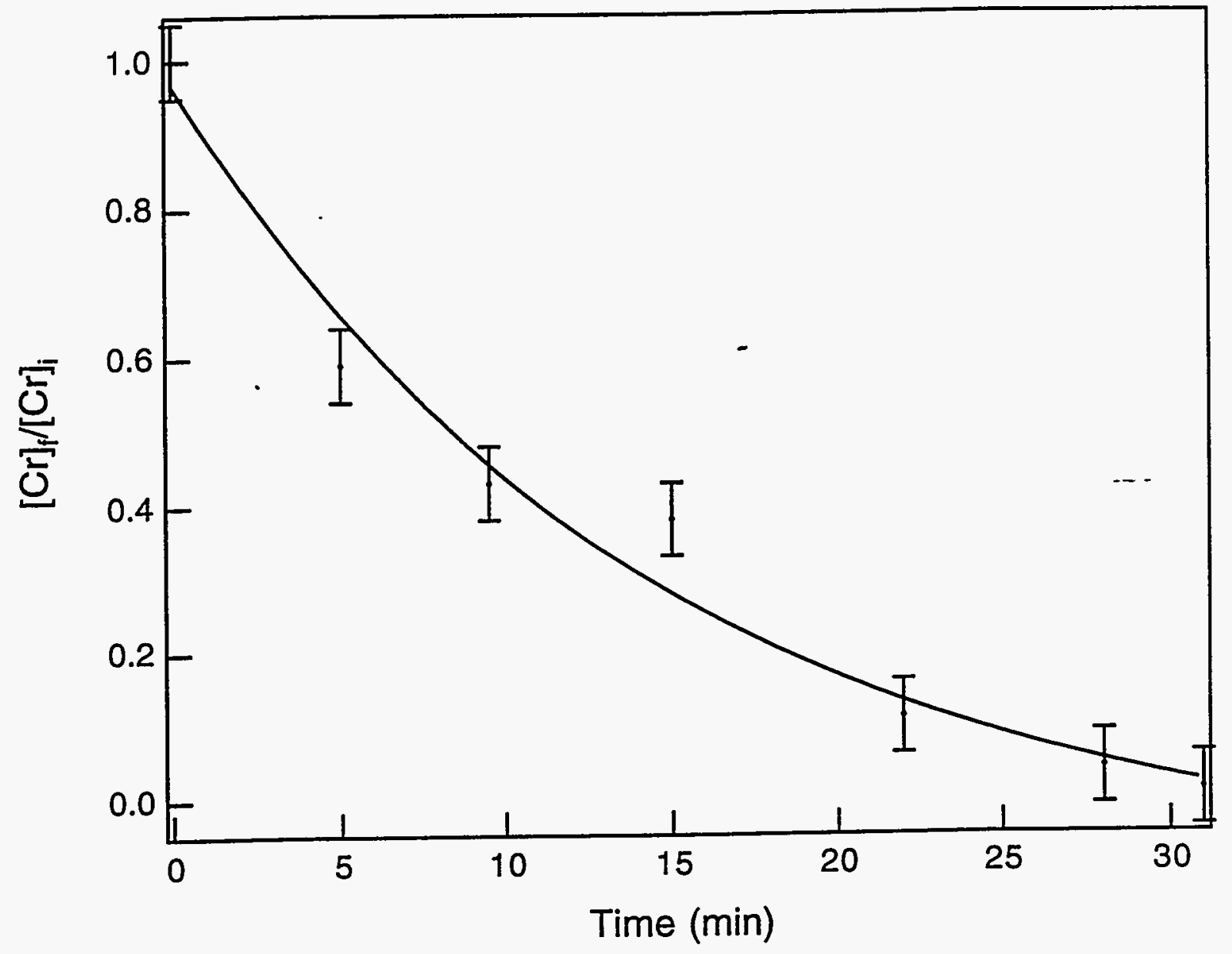

Figure 2. Rate of hydrothermal oxidative dissolution of $\alpha-\mathrm{Cr}_{2} \mathrm{O}_{3}$ (2\% by weight) in $\mathrm{NaOH}$ solution, using $\mathrm{H}_{2} \mathrm{O}_{2}$ as oxidant (equation 1 ). 


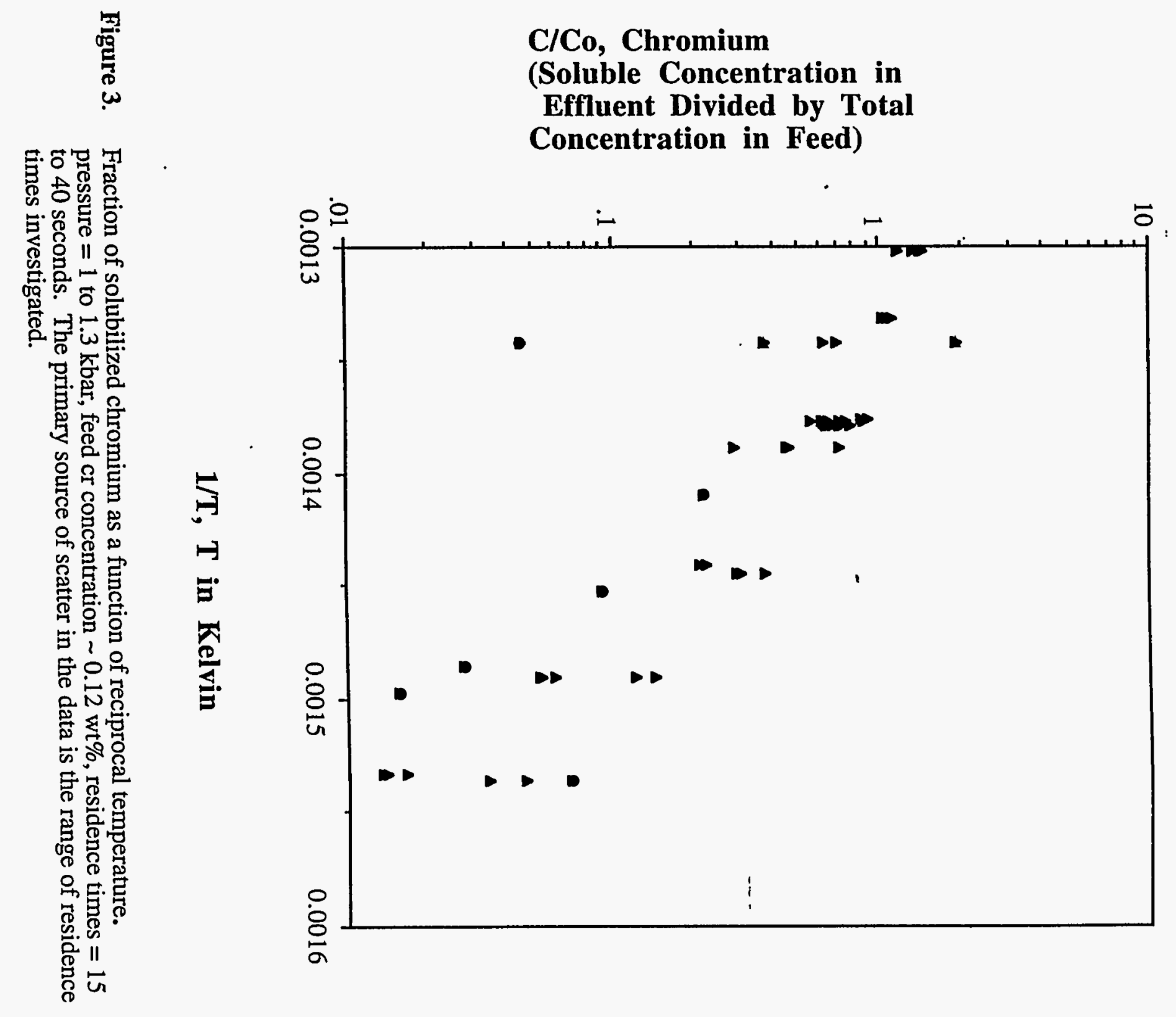




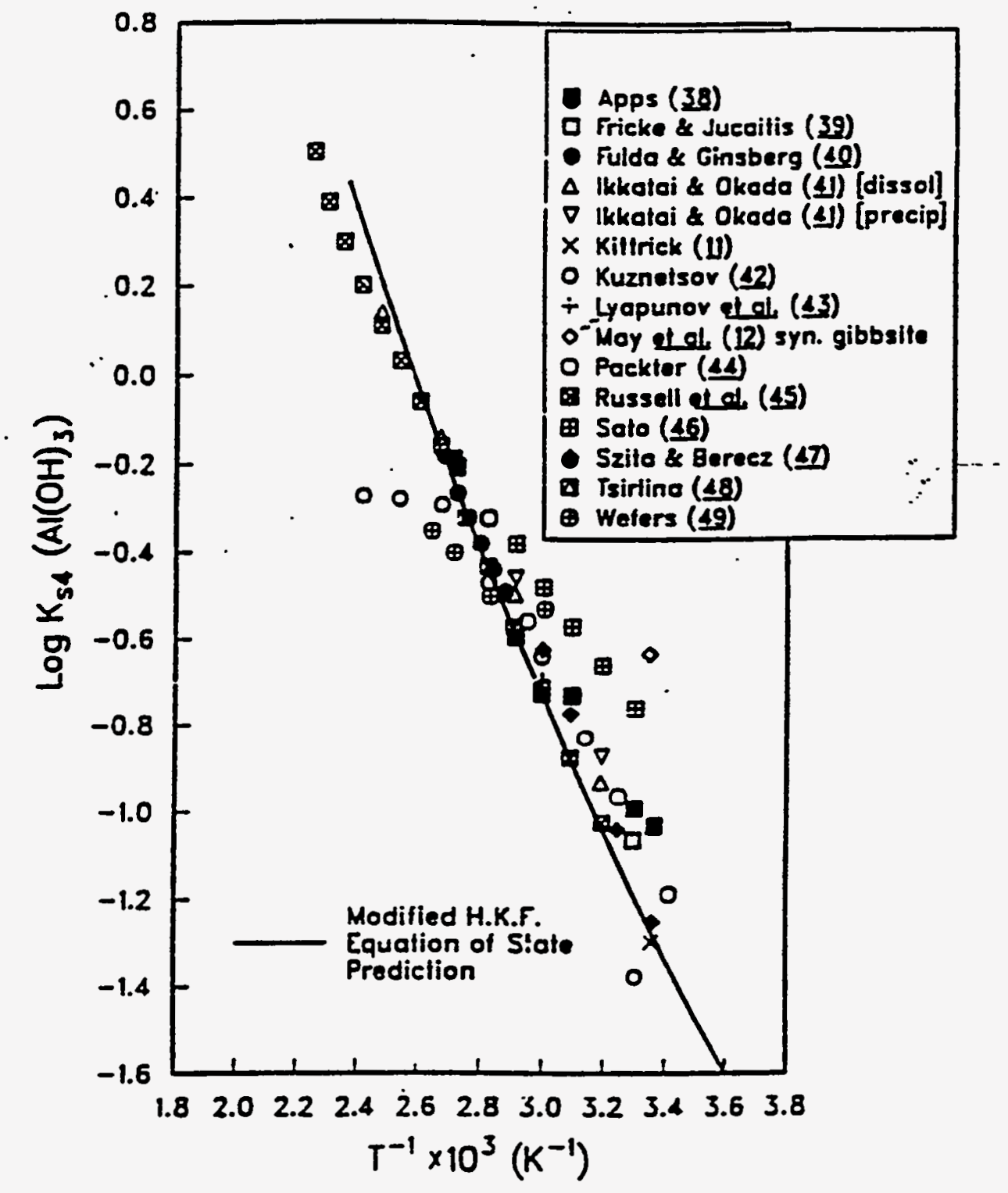

Figure 4. Plot of $\log \mathrm{K}_{\mathrm{S}}\left(\mathrm{Al}(\mathrm{OH})_{3}\right)$ versus the reciprocal of absolute temperature, in which solubility measurements attributed to gibbsite are compared [10]. 


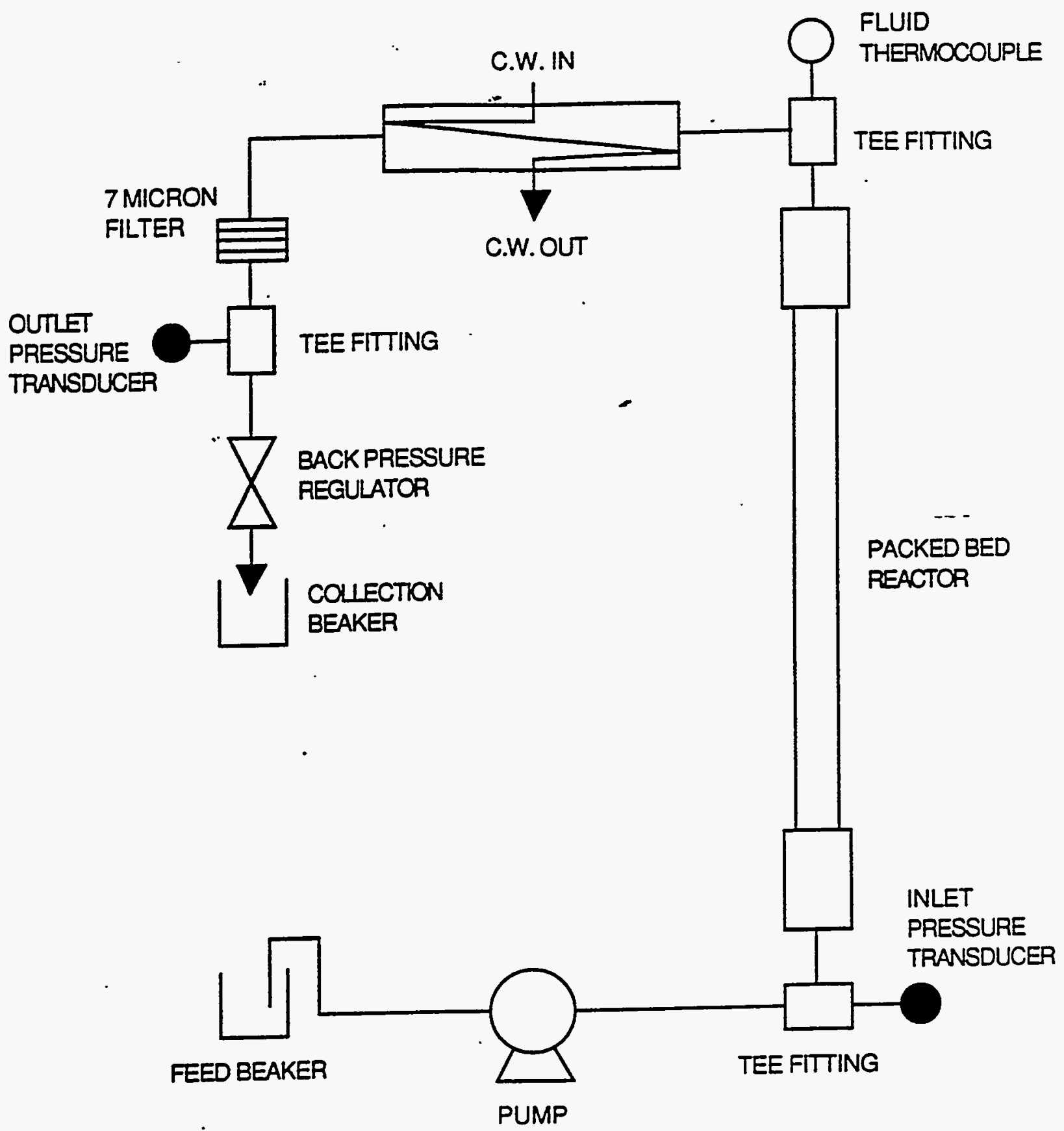

Figure 5. Schematic of packed bed hydrothermal solubility apparatus. 